\title{
The Policy Arrangement of Taxation Management Agency in West Java
}

\author{
P. Bestari \\ Civic Education Department, Faculty of Social Science Education \\ Universitas Pendidikan Indonesia \\ Bandung, INDONESIA \\ yogabestari@yahoo.co.id
}

\begin{abstract}
Tax is the main sector and still be seeded source of national income. But until now tax management is not effective and efficient. It caused by several factors including: 1) the weak public awareness of paying taxes; 2) system of tax management has not professional yet; 3) policy of tax management is not effective; 4 ) socialization of tax policy is not effective; 5 ) facility and infrastructure of tax collecting inadequate In the public policy, there should be a deep policy study related to the mechanism of taxation systems. Thus, focus of paper is the policy arrangement of taxation management agency in West Java province. As for the finding of the study expected with all alternative policies that can be taken in increase the effectiveness and efficiency of tax management. In order that all stakeholders pertaining with taxation can well understand and will raise the role in increasing national income from tax sector.
\end{abstract}

Keywords: policy, tax, effectiveness, socialization

\section{INTRODUCTION}

The policy arrangement in tax sector is a movement the West Java provincial government to increase the tax absorption in regional and local revenue itself from tax sector. Based on the data from Central Statistics Agency in 2014 obtained that the urban people in Indonesia has reached more than 50 percent of total Indonesian population. This number likely to increase each year, it is expected the number of people who live in the urban will reach $67 \%$ in years 2035 . The data suggests that Indonesian people has been increasing each time. Thus, along with increased the number of people from time to time, then need to tax management by the government to meet the needs of public life.

\section{RESEARCH PROBLEM}

West Java is one of the highest population in Indonesia with large economic activity. But from the research that has been done, tax absorption in West Java has not been as expected. From the research before, known that there are several problems that occurring in tax management in West Java government, they are: 1) the weak awareness of people to pay taxes; 2) system of tax management has not professional yet; 3) policy of tax management is not effective; 4) socialization of tax policy is not effective; 5) facility and infrastructure of tax collecting inadequate.

From these problems, it can be said that the policy of socialization becomes one of the important factors in structuring taxation policy of the West Java province. Some reasons for the importance of structuring tax management in socialization term are: 1) the low understanding of the people against the tax payment mechanism causing public awareness in paying taxes is still low; and 2) media used in socialization has not been effective and efficient. Thus in terms of structuring tax management policies in the West Java province must held with the socialization policy arrangement of tax management.

\section{LITERATURE REVIEW}

Some experts have an opinion about the importance of a policy socialization. According to Brim (1994) ${ }^{[1]}$ socialization as the process whereby a person acquiring knowledge, basic ability which causes they are able or not to be a member of group. This sense see socialization as a learning process where individual learn and obtain the value of he enters groups. Next, Hetherington and Parke (1999) ${ }^{[2]}$ mentioned that socialization as a process of forming individual standard about skill, encouragement the attitudes and behavior that would be as demand and expectation of society.

The formation of standard individual was obtained from parents from birth to be adult. Socialization is a process whole life from birth to the living end. It can be concluded that socialization can be defined as the process that puts the community to know and understand norms or values where they become members in order to play role in accordance with norms or those values are. Thus, socialization arrangement of tax management in the West Java province should be performed with purpose the community understanding of the tax payment mechanism itself and of public awareness in fulfill their obligations to pay taxes. In West Java government, there are several institutions that on duty to handle tax management such as Department of Local Revenue and the Director General of West Java Local Taxes. In practice, West Java Local Revenue Department have the obligation to manage and facilitate the tax payment service in an area to have a partnership with sectors in the field as one of them Samsat for the vehicle tax sector. Department of Local Revenue has a duty to gather taxes in West Java area, therefore Department of Local Revenue has the authority also to make this tax management policy.

Till at this time the policy of tax management has not work effective and efficient yet. Such a problem can be seen from the low awareness of people to pay tax that is directly proportional to the low absorption of tax itself. Of the problem is the most be highlighted is related to the socialization. According to Mardiasmo, (2008: 2) ${ }^{[3]}$ in order to tax collection does not cause obstacles, then tax collection must be qualified tax collection, as follows:

a) Justice condition. Taxes collecting should be fair consistent with the legal purposes even up to justice based on the act in impose a tax in general and evenly, and adjusted to 
the ability of each people. While just in the operations will be done by give the right for taxpayers to lodge a challenge to the Head of Tax Service, and appeal to tax court.

b) Juridical condition. Taxes collecting should be based on the act. In Indonesia tax arranged in the constitution Undang-Undang Dasar Tahun 1945 article 23 caluse (2). This provides legal security to bring justice, for the state and its citizens.

c) Economical condition. Taxes collection may not disrupt the economic activities, not only but also the trade, and avoid the economic sluggishness .

d) Financial condition. Taxes collecting should be efficient according as budgetair function. The cost of taxes collecting should be able to save so that lower than the result of the collection.

e) Taxes collecting system should be simple. The simple taxes collecting system will encourage the people in pay a taxation obligation. This requirement have been meet by new taxation act.

Looking at the analysis above, requirements of taxes collecting not only to be understood by stakeholders. But the requirements of taxes collecting as delivered Mardiasmo above should be internalized to the community as taxpayers. Internalization the implied meaning in requirements of taxes collecting above is very important to do to taxpayers in order to a grow understanding within the people about the importance of pay taxes.

It is necessary to be delivered in the tax socialization to the people. So that we can conclude that socialization is not only relating to the appeal for taxpayers to pay taxes, but also it should encourage the understanding and awareness about the importance of pay taxes.

\section{METHODS}

An approach that used in this research was a qualitative approach. Research process which is expected to take place in natural background where researchers are the main instrument. This study has been done by means of explorative research. Researchers directly to the field to collect the data.

\section{RESULT}

This study aims to emphasize the importance of the tax management socialization to West Java, should be done by effective and efficient collecting system starting from socialization, the to tax management. From the research had previously been produced Mobile Tax Car as an alternative for tax socialization in West Java. It can help the local taxes absorption and educate to the people about the importance of pay taxes.

After perceiving problems of tax management in West Java province, it can reaffirmed that it can be started in order to arrange tax management policy in West Java province is started by improvement the socialization mechanism for more effective and efficient.This socialization pertaining to a problem nucleus in taxes collecting such as the weak awareness of people to pay tax and poor tax absorption in West Java province. In addition, the event was not just urged taxpayers to pay taxes. But the program will be expected to build understanding and awareness the taxpayers.

Next, Department of Local Revenue in West Java (central) responsible for the implementation of the regional government business in the field of local revenue based on autonomy principle and co-administration funds. As for its function covering, the formulating and determination of revenue technical policy; holding the related things with income and public services, planning and development, tax, non-tax, control and guidance (Branches of Revenue Department Service); an organizer of the facilities to apply the income duties internally include secretarial, planning and development, tax, non-tax, control and development Branches of Revenue Department Service, guidance functional technic, Regional Income and Common Service; the other task from the Governor in accordance with duties and functions. From exposure can be seen that the duties of the Department of Local Revenue in West Java includes various taxation affairs which happened to the administrative region of West java province. Branches of Revenue Department Service founded usually consists Region I and Region II. The duties and functions were same, but the difference is the area that become the scope of services. For example, Branches of Revenue Department Service in Bandung as follows:

Table 1.1

Territorial Division of Branches of Revenue Department Service in Bandung

\begin{tabular}{|c|c|c|c|}
\hline No & District/City & $\begin{array}{l}\text { Branches of } \\
\text { Revenue } \\
\text { Department } \\
\text { Service }\end{array}$ & Service Area \\
\hline 1 & Bandung City & $\begin{array}{l}\text { Branches of } \\
\text { Revenue } \\
\text { Department } \\
\text { Service in } \\
\text { Province } \\
\text { Region } \\
\text { Bandung City } \\
\text { I Pajajaran }\end{array}$ & $\begin{array}{l}\text { 1. Subdistrict Sukasari; } \\
\text { 2. Subdistrict Sukajadi; } \\
\text { 3. Subdistrict Cicendo; } \\
\text { 4. Subdistrict Andir; } \\
\text { 5. Subdistrict Astana Anyar; } \\
\text { 6. Subdistrict Bojongloa } \\
\text { Kaler; } \\
\text { 7. Subdistrict Bojongloa } \\
\text { Kidul; } \\
\text { 8. Subdistrict } \\
\text { Ciparay; Babakan } \\
\text { 9. Subdistrict } \\
\text { Kulon. Bandung }\end{array}$ \\
\hline 2 & Bandung City & $\begin{array}{l}\text { Branches of } \\
\text { Revenue } \\
\text { Department } \\
\text { Service in } \\
\text { Province } \\
\text { Region } \\
\text { Bandung City } \\
\text { II Kawaluyan }\end{array}$ & $\begin{array}{l}\text { 1. Subdistrict Regol; } \\
\text { 2. Subdistrict Lengkong; } \\
\text { 3. Subdistrict Kiara } \\
\text { Condong; } \\
\text { 4. Subdistrict Batununggal; } \\
\text { 5. Subdistrict Cidadap; } \\
\text { 6. Subdistrict Coblong; } \\
\text { 7. Subdistrict Bandung } \\
\text { Wetan; } \\
\text { 8. Subdistrict Sumur } \\
\text { Bandung; } \\
\text { 9. Subdistrict Cibeunying } \\
\text { Kaler; } \\
\text { 10. Subdistrict Cibeunying } \\
\text { Kidul. }\end{array}$ \\
\hline
\end{tabular}

a. Source: Appendix of the Governor Regulation Number 17 Year 2013 about The Main Task, Function, Details Duty Units and Work Systems of Technical Unit Offices In Environment The Revenue 
In practice, management is divided with involving 34 Office Branch which scattered in each district in the entire West Java province. Finally, at the central, specifically take care of the vehicle taxes problem start on until the policy determination governing technical services. Nevertheless, Department of Local Revenue in West Java in terms of vehicle tax service involving office branch as supportable resources for effectiveness.

Based on Governor Regulation Number 17 Year 2013, Department of Local Revenue in its duties, helped by Technical Unit which is branch of Department of Local Revenue service in West Java its located in District/City and central of information management and revenue application agency, with a component of the Department Branch Services. The duties are explained through article 3 Governor Regulation Number 17 Year 2013, they are: main task of the branch is implement part of Department of Local Revenue West Java function in regional income field. Present function such as, the material study of technical guidelines in the regional income field and the implementation of services in regional income field. Of these functions broken down the duty of the Branch Services Agency, which is:

\section{a) Compile the program of Branch Service Agency;}

b) Hold the study material of technical guidelines in the regional income field;

c) Organize the services in the regional income field;

d) Controlling, evaluating, reporting, and coordinating in the field of regional income; agency;

e) Implement the administrative of the branch services

f) Analyze staff for consideration of decision-making;

g) Coordination with the related unit; and

h) Working on other task, in accordance with duties and functions .

The tasks are held by the organizational structure, namely:

a) The chief/head;
b) Administrative sub-section
c) Division of revenue and determination
d) Division of receipt and billing;
e) Group of functional positions; and
f) Branch of service.

On a scale branches of the office, relating to terms of the receipt and billing, as mentioned in article 7 West Java Governor Regulation Number 17 Year 2013, carried out the arrangement of technical guidelines material, receipt service, billing, objections and appeal, coordination, control the reporting revenue evaluation, explanation about vehicle tax, motor vehicle rename tax, fuel tax of motor vehicle, cigarette tax, and local revenue.

Based on a survey and interview found that division of domain management are carried between branches of the office and the central office. Simply Department of Local Revenue in
West Java having concerned about vehicle tax and motor vehicle rename tax and branches of the office manage local revenue in addition. This can be explained based on current development. The division of the Department of Local Revenue into branches of the office, tax management finally done separately .

Associated with fuel tax of motor vehicle, cigarette tax and others are managed and designed technical policy in relation service by branches that coordinated to the Department of Local Revenue West Java. The development of strategy to optimize local revenue by the tax impressed not too show progressive and visionary innovation. But programs which is managed by the Department of Local Revenue West Java directly, covering:

a) E-Samsat West Java;

b) Sentralise Online Samsat;

c) Online Samsat 3 provinces;

d) Samsat Nampi Iuran Wajib Ti Wengi (NITE);

e) Online Samsat;

f) Outlet Samsat;

g) Outlet Samsat Bank of West Java;

h) Mobile Samsat;

i) ISO-9001-2000 Samsat;

j) Drive Thru Samsat.

Next, relating to innovation who has been done, it's not always emerged from the initiative of the Department of Local Revenue, but synergy of the Department of Local Revenue province with branch of service agency and also district/city often give an advice even give space for the expansion of service, it was proven by implemented the T-Samsat in the Sukabumi district. It is caused partner (in this case the third party: lising and cooperation) that is cooperative and representative to approve the service parternship and allow in terms of policy without changing function service prescribed by act and regulations/policies on.

Sukabumi has applied such a system, well it turns out when the prototype submitted to other areas, condition was different, especially in urban area. Third party policy is very tight and relative irrelevant to be applied T-Samsat in of this. The difference is the third party policy in Sukabumi centered where the third party operated, but the third party in urban usually integrated into the center, both lising and large cooperation. In sukabumi, branch of service agency work with cooperation from active and integrated association of profession with all levels of workers, so that it easy to apply T-Samsat .

\section{CONCLUSION}

The arrangement of tax management policy in West Java province started by improvement for more effectively and efficiently socialization mechanism. This socialization pertaining to a nucleus problem on taxes collecting that the weak awareness of people to pay tax and poor tax absorption in West Java province. In addition, the event was not just urged taxpayer to pay taxes. But the program will be expected to 
build understanding and awareness the taxpayer to pay taxes. Socialization should be massive, constructive, and intensively effort about the payment of tax process. Socialization needs to apply the pattern adapted to characteristic of people (conventional and modern).

The expected advantages of paper about the policy arrangement of tax management in West Java with the improvement on more effective and efficient socialization mechanism is as follows:

1) Policy of management taxation board in West Java has to have some technical taxation agreement especially related to collecting and socialization tax and publication the results of taxation. Coordination, consolidation, and interactive communication can be solution to increase the effectiveness of policy on taxes in West Java.

2) The effectiveness performance of taxation board policy is not only measured by the user/customer understanding in case citizens. But also a accurate understanding of the taxes stewards or taxation institution itself. The most fundamental is how the officer mindset in taxes field can be changed: 1 ) from who want to be served become used to serve; 2 ) From "waiting for the ball" or waiting to be paying taxes become "pick up the ball" or come up to someone who will pay taxes; 3 ) from conventional service or manual become online/website based service; 4 ) from not transparent become transparent in service or managerial; and 5 ) From not love to smile become friendly (humanist-familial).

3) For the institution of West Java provincial government: the policy arrangement of the tax policy socialization can be used different innovations, one of them use Mobile Tax Car as socialization solution and efforts to improve the effectiveness of tax collection. The use of Mobile Tax Car is an innovation or breakthrough in terms of increasing the understanding and public awareness in pay tax will led to the tax absorption.

4) For society: socialization of tax management through Mobile Tax Car can be used as media to facilitate the people as taxpayer in fulfill their pay taxes obligations effectively and efficiently.

\section{REFERENCES}

[1] Brim. (1994). Socialization after Childhood. New York : Two Essay Wiley

[2] Hetherington, E.M \& Parke, R.D. (1999).Child Psychology (5th edition).USA: McGraw-Hill Collage. 